\title{
Similarities and differences in trends of changes of the agroclimatic conditions of the main viticulture zones of the Krasnodar region
}

\author{
Evgeniy Chernikov*, Anna Marmorshtein, Valentina Popova, and Galina Aleynikova \\ Federal State Budget Scientific Institution «North Caucasian Federal Scientific Center of \\ Horticulture, Viticulture, Wine-making», 39 str. 40 Let Pobedy, Krasnodar, 350901, Russia
}

\begin{abstract}
In this article are presented the results of studying the similarities and differences in the trends of changes of the agroclimatic conditions of the main viticulture zones of the Krasnodar region according to the data of the Temryuk, Anapa and Taman weather stations. The average values of heat and water supply indicators for two thirty-year (1961-1990, 1991-2020) and three twenty-year averaging periods (19611980, 1981-2000, 2001-2020) were obtained. Statistically significant changes in the average agroclimatic indicators were noted. The connection of the course of indicators between weather stations is determined, especially a close connection is noted in the indicators of Anapa and Temryuk. The values of linear trends in 1991-2020 for Anapa and Temryuk are calculated. Statistically significant trends are the growth of the accumulated air temperature above $+10{ }^{\circ} \mathrm{C}$ in Anapa and Temryuk, a decrease in the moisture coefficient and an increase in the dryness index in Temryuk.
\end{abstract}

\section{Introduction}

Climate is a long-term weather regime. The period 1961-1990 is considered a standard reference period and is used for long-term assessment of climate change. Climatological standard normals change every decade - the previous period was 1981-2010, currently the base climatic period should be compared with the last 30-year period of 1991-2020 [1]. However, the average climatological data for twenty-year periods are also interesting, according to which it is possible to consider in more detail the changes that are not observed during longer averaging periods.

Climate and its changes are important in many sectors of the economy, especially in agriculture: favorable changes carry an expansion of plantings and an increase in yield capacity, unfavorable ones cause the opposite consequences and a large anthropogenic load.

There are several main directions of the studies of climate change in the scientific fields of viticulture and winemaking:

- agro-climatic zoning of viticultural regions, assessment of their suitability [2-6];

\footnotetext{
*Corresponding author: garden_soil@mail.ru
} 
- forecasting future climate changes in the world viticultural regions using mathematical models [7-10];

- study of the influence of new climatic and extreme weather conditions on the vine, yield capacity and quality of grapes and products from it [11-15];

- development of methods of adaptation to new environmental conditions [16-19].

In Russia, the study of the climate influence on the grape plant is also relevant in all directions [20-22]. Previously, we carried out a detailed study of climate change in Temryuk from 1960 to 2019 - both indicators of heat supply and moisture supply, and their relationship with changes in soil characteristics [23]. However, it is of interest to study the similarities and differences of climate changes in relatively close and important for viticulture territories.

The goal of the research is to study the similarities and differences in trends of the agroclimatic conditions of the main viticulture zones of the Krasnodar region.

\section{Materials and Methods}

The study of changes of the agro-climatic conditions of the main viticulture zones of the Krasnodar region was carried out using daily and decadal meteorological data of Anapa and Temryuk for the period 1961-2020 and Taman for the period 1961-1990, 2009-2015. The sixty-year period is divided into two thirty-year periods (1961-1990 and 1991-2020) and three twenty-year periods (1961-1980, 1981-2000 and 2001-2020) for the analysis of changes.

The following indicators were selected for the study of agro-climatic conditions: the accumulated air temperature above $+10{ }^{\circ} \mathrm{C}$, the total precipitation for the period with air temperatures above $+0{ }^{\circ} \mathrm{C},+10{ }^{\circ} \mathrm{C}$, April-October and annual precipitation, moisture availability parameters - Sapozhnikova's Moisture coefficient (MC), Selyaninov's hydrothermal coefficient (HTC) and Budyko's dryness index (DI) [24].

Three approaches were used to assess agro-climatic conditions and their changes:

- averaging of each agrometeorological indicator for the selected periods. For Taman averaging was carried out only for 1961-1990 and 1961-1980);

- correlation analysis of the course of agrometeorological indicators for all periods. The values of the correlation coefficients for the indicators of Taman for the period 20092015 with the indicators of Anapa and Temryuk were found;

- determination of linear trends of agrometeorological indicators for the period from 1991 to 2020 for Anapa and Temryuk.

The statistical significance of changes in averages and trends was determined using the Student's criterion.

\section{Results and Discussion}

The average values of the period 1961-1990 showed that the accumulated air temperature above $+10^{\circ} \mathrm{C}$ was slightly higher in Anapa. Taman was the driest because of the least total precipitation among the stations. This was confirmed by Taman's DI (the higher the index value, the more arid the territory is).

According to the comparison of the average values of agro-climatic indicators for two thirty-year periods 1961-1990 and 1991-2020, statistically significant were the changes in the average values of the accumulated air temperatures above $+10{ }^{\circ} \mathrm{C}$ in Anapa and Temryuk, the total precipitation for the period with air temperatures above $0{ }^{\circ} \mathrm{C}$ and the annual precipitation in Anapa (Table 1). 
Table 1. Average values of agro-climatic indicators for two thirty-year periods: 1961-1990 and 19912020 and for three twenty-year periods: 1961-1980, 1981-2000 and 2001-2020.

\begin{tabular}{|c|c|c|c|c|c|c|c|c|}
\hline 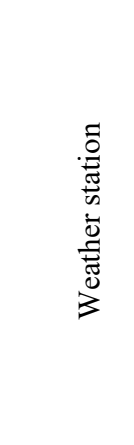 & 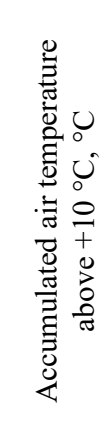 & 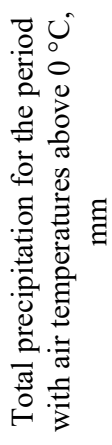 & 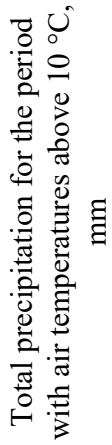 & 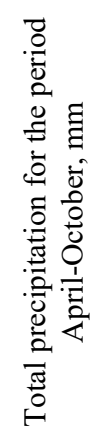 & 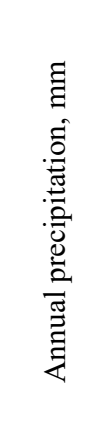 & 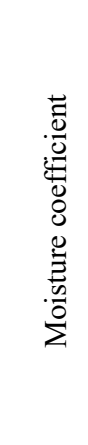 & 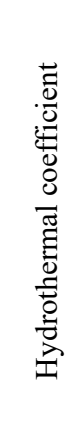 & 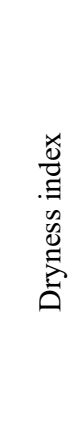 \\
\hline \multicolumn{9}{|c|}{ Thirty-year average } \\
\hline \multicolumn{9}{|c|}{$1961-1990$} \\
\hline Anapa & $3604.8^{\mathrm{a}}$ & $472.5^{\mathrm{c}}$ & 255.9 & 265.4 & $524^{\mathrm{d}}$ & 0.63 & 0.57 & 1.29 \\
\hline Temryuk & $3590.4^{\mathrm{b}}$ & 443.2 & 258.6 & 269.8 & 511.4 & 0.63 & 0.56 & 1.31 \\
\hline Taman & 3561.7 & 351.1 & 193.3 & 213.5 & 421.7 & 0.65 & 0.48 & 1.59 \\
\hline \multicolumn{9}{|c|}{$1991-2020$} \\
\hline Anapa & $3934.3^{\mathrm{a}}$ & $550^{c}$ & 285.2 & 297.3 & $566.4^{\mathrm{d}}$ & 0.63 & 0.52 & 1.3 \\
\hline Temryuk & $3797.5^{\mathrm{b}}$ & 465.9 & 273.9 & 293.3 & 534.2 & 0.64 & 0.61 & 1.33 \\
\hline \multicolumn{9}{|c|}{ Twenty-year average } \\
\hline \multicolumn{9}{|c|}{$1961-1980$} \\
\hline Anapa & 3611.2 & $454.5^{\mathrm{e}}$ & 250 & 259.8 & 513.3 & 0.6 & 0.53 & 1.3 \\
\hline Temryuk & 3582.3 & 434 & 250.7 & 263.4 & $491.3^{\mathrm{f}}$ & $0.6^{\mathrm{c}}$ & 0.53 & $1.36^{\mathrm{g}}$ \\
\hline Taman & 3577.4 & 335.6 & 191 & 206.4 & 397.2 & 0.7 & 0.44 & 1.69 \\
\hline \multicolumn{9}{|c|}{$1981-2000$} \\
\hline Anapa & $3634^{\mathrm{h}}$ & $536.3^{\mathrm{e}}$ & 269.9 & 290.5 & 565 & 0.68 & 0.59 & 1.23 \\
\hline Temryuk & $3599.8^{\mathrm{i}}$ & 454 & 274.7 & 293.3 & $545.9^{f}$ & $0.68^{\mathrm{cj}}$ & 0.61 & $1.23^{\mathrm{g}}$ \\
\hline \multicolumn{9}{|c|}{$2001-2020$} \\
\hline Anapa & $4063.6^{\mathrm{h}}$ & 542.9 & 291.7 & 293.8 & 557.2 & 0.61 & 0.5 & 1.36 \\
\hline Temryuk & $3899.8^{\mathrm{i}}$ & 474.8 & 273.3 & 288 & 531.3 & $0.61^{\mathrm{j}}$ & 0.6 & 1.38 \\
\hline
\end{tabular}

Note: Values with different letters are significantly different $(\mathrm{p} \leq 0.05)$

In the period of 1961-1980, Anapa was distinguished by the accumulated air temperature. In the period 2001-2020, the difference between the stations only increased. Taman was distinguished by the aridity in the period 1961-1980.

The changes in the total precipitation over the period with air temperatures above $0{ }^{\circ} \mathrm{C}$ and the accumulated air temperatures above $+10^{\circ} \mathrm{C}$ for 1981-2000 compared to 1961-1980 were statistically significant in Anapa. In the case of Temryuk, the average values of the following indicators changed statistically significantly for the period 1981-2000, compared to 1961-1980: the annual precipitation, the MC and the DI. The averages for the period 2001-2020 had changed significantly only for the indicators of the accumulated air temperatures above $+10{ }^{\circ} \mathrm{C}$ and the $\mathrm{MC}$.

For a more accurate comparison of the conditions of three places important for viticulture in the Krasnodar region, agrometeorological indicators were correlated for different periods for three stations: Anapa/Temryuk (1961-1990, 1991-2020, 19611980,1981-2000, 2001-2020) and Temryuk/Taman, Anapa/Taman (1961-1990, 1961-1980, 2009-2015). Agrometeorological indicators of Temryuk and Anapa in all periods have a 
statistically significant strong or average relationship, with the exception of MC 1961-1980 and HTC 1961-1990 and 1981-2000 (Table 2).

Statistically significant in the modern period (2009-2015) was the relationship of the accumulated air temperature above $+10^{\circ} \mathrm{C}$ in Taman with the data from Temryuk and Anapa, in the case of Temryuk, the relationship of the DI was also significant and high.

Table 2. The values of the correlation coefficients of agrometeorological indicators for different periods in Temryuk, Anapa and Taman.

\begin{tabular}{|c|c|c|c|c|c|c|c|c|}
\hline $\begin{array}{l}\overrightarrow{0} \\
\frac{0}{0}\end{array}$ & 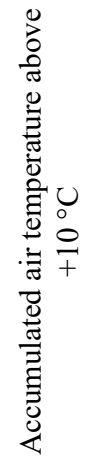 & 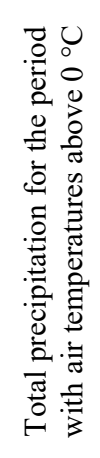 & 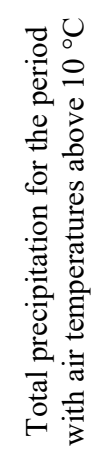 & 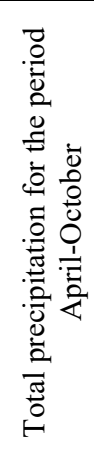 & 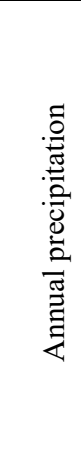 & 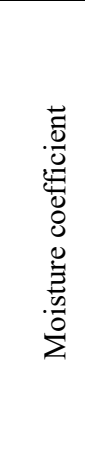 & 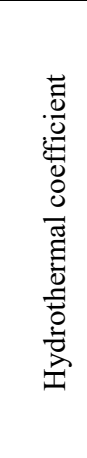 & 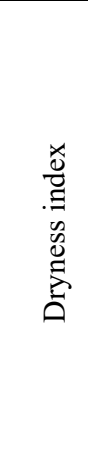 \\
\hline \multicolumn{9}{|c|}{ Temryuk/Anapa } \\
\hline 1961-1990 & $0.86^{\mathrm{a}}$ & $0.83^{\mathrm{a}}$ & $0.59^{\mathrm{b}}$ & $0.56^{\mathrm{b}}$ & $0.73^{\mathrm{a}}$ & $0.54^{\mathrm{b}}$ & $0.42^{\mathrm{c}}$ & $0.7^{\mathrm{b}}$ \\
\hline 1991-2020 & $0.77^{\mathrm{a}}$ & $0.58^{\mathrm{b}}$ & $0.6^{\mathrm{b}}$ & $0.63^{\mathrm{b}}$ & $0.61^{\mathrm{b}}$ & $0.57^{\mathrm{b}}$ & $0.67^{\mathrm{b}}$ & $0.62^{\mathrm{b}}$ \\
\hline 1961-1980 & $0.83^{\mathrm{a}}$ & $0.72^{\mathrm{a}}$ & $0.61^{\mathrm{b}}$ & $0.60^{\mathrm{b}}$ & $0.67^{\mathrm{b}}$ & $0.48^{\mathrm{c}}$ & $0.64^{\mathrm{b}}$ & $0.66^{\mathrm{b}}$ \\
\hline $1981-2000$ & $0.84^{\mathrm{a}}$ & $0.87^{\mathrm{a}}$ & $0.69^{\mathrm{b}}$ & $0.71^{\mathrm{a}}$ & $0.73^{\mathrm{a}}$ & $0.6^{\mathrm{b}}$ & $0.45^{\mathrm{c}}$ & $0.77^{\mathrm{a}}$ \\
\hline $2000-2020$ & $0.77^{\mathrm{a}}$ & $0.58^{\mathrm{b}}$ & $0.6^{\mathrm{b}}$ & $0.63^{\mathrm{b}}$ & $0.61^{\mathrm{b}}$ & $0.57^{\mathrm{b}}$ & $0.67^{\mathrm{b}}$ & $0.62^{\mathrm{b}}$ \\
\hline \multicolumn{9}{|c|}{ Temryuk/Taman } \\
\hline 1961-1980 & $0.88^{\mathrm{a}}$ & $0.78^{\mathrm{a}}$ & $0.48^{\mathrm{c}}$ & $0.59^{\mathrm{b}}$ & $0.73^{\mathrm{a}}$ & 0.32 & 0.29 & $0.83^{\mathrm{a}}$ \\
\hline 1961-1990 & $0.87^{\mathrm{a}}$ & $0.6^{\mathrm{b}}$ & $0.57^{\mathrm{b}}$ & $0.57^{\mathrm{b}}$ & $0.8^{\mathrm{a}}$ & 0.26 & 0.44 & $0.84^{\mathrm{a}}$ \\
\hline 2009-2015 & $0.93^{\mathrm{a}}$ & 0.56 & 0.46 & 0.44 & 0.73 & 0.61 & 0.32 & $0.85^{\mathrm{a}}$ \\
\hline \multicolumn{9}{|c|}{ Anapa/Taman } \\
\hline 1961-1980 & $0.83^{\mathrm{a}}$ & $0.8^{\mathrm{a}}$ & 0.36 & $0.42^{\mathrm{c}}$ & $0.75^{\mathrm{a}}$ & 0.08 & $0.59^{\mathrm{b}}$ & $0.75^{\mathrm{a}}$ \\
\hline 1961-1990 & $0.85^{\mathrm{a}}$ & $0.72^{\mathrm{a}}$ & $0.59^{\mathrm{b}}$ & $0.64^{\mathrm{b}}$ & $0.67^{\mathrm{b}}$ & 0.15 & 0.16 & $0.68^{\mathrm{b}}$ \\
\hline 2009-2015 & $0.83^{\mathrm{a}}$ & 0.42 & 0.45 & 0.38 & 0.23 & 0.25 & 0.43 & 0.11 \\
\hline
\end{tabular}

Note: The values of the correlation coefficient with different letters are considered statistically significant at $\mathrm{p} \leq 0.05$ : a is a strong relationship ( $r>0.7)$, $\mathrm{b}$ is an average relationship $(0.5<\mathrm{r} \leq 0.7)$, $\mathrm{c}$ is a weak relationship $(0.3<\mathrm{r} \leq 0.5)$.

Linear trends of agrometeorological indicators in Anapa and Temryuk for the period 1991-2020 were also calculated. Statistically significant were the increase in the accumulated air temperature above $+10{ }^{\circ} \mathrm{C}$ in Anapa and Temryuk, a decrease in the $\mathrm{MC}$ and an increase in the DI in Temryuk. The increase in the accumulated air temperature above $+10{ }^{\circ} \mathrm{C}$ in Anapa was faster than in Temryuk. The rate of increase in aridity of the territory was more significant and higher in Temryuk. In general, almost all linear trends indicated an increase in the aridity of the territory, in contrast to the average values - an increase in the accumulated air temperature and a decrease in precipitation (with the exception of the total precipitation for the period with air temperatures above $10{ }^{\circ} \mathrm{C}$ in Anapa - an insignificant increase) (Table 3).

Table 3. Linear trends of agrometeorological indicators in Anapa and Temryuk, 1991-2020.

\begin{tabular}{|c|c|c|}
\hline Agrometeorological indicator & Anapa & Temryuk \\
\hline Accumulated air temperature above $+10{ }^{\circ} \mathrm{C},{ }^{\circ} \mathrm{C} / 10$ years & $260.3^{*}$ & $198.6^{*}$ \\
\hline Total precipitation for the period with air temperatures above $0{ }^{\circ} \mathrm{C}$, & -9.76 & -19.17 \\
\hline
\end{tabular}




\begin{tabular}{|c|c|c|}
$\mathrm{mm} / 10$ years & & \\
\hline Total precipitation for the period with air temperatures above 10 & 13.86 & -16.72 \\
\hline $\begin{array}{c}{ }^{\circ} \mathrm{C}, \mathrm{mm} / 10 \text { years } \\
\text { Total precipitation for the period April-October, mm/10 years }\end{array}$ & -0.2 & -27.8 \\
\hline Annual precipitation, $\mathrm{mm} / 10$ years & -13.3 & -35.25 \\
\hline Moisture coefficient, ...10 years & -0.04 & $-0.086^{*}$ \\
\hline Hydrothermal coefficient, .../10 years & -0.051 & -0.074 \\
\hline Dryness index, .../10 years & 0.11 & $0.18^{*}$ \\
\hline
\end{tabular}

Note: The trend values marked with * have statistical significance at $\mathrm{p} \leq 0.05$

\section{Conclusion}

Generally, it should be noted that there were more statistically significant changes in agrometeorological indicators when comparing two thirty-year periods in Anapa than in Temryuk. However, the variability of averages was higher in Temryuk when comparing twenty-year periods. The course of agrometeorological indicators in Anapa and the course in Temryuk were interrelated. In the period 2009-2015, a closer relationship was observed between the indicators of Taman and the indicators of Temryuk, however, in earlier and longer periods, both the indicators of Temryuk and the indicators of Anapa had approximately the same relationship with the Taman's indicators. According to linear trends, there was an increase in the aridity of the territory, mostly in Temryuk, despite the increasing average values of agro-climatic indicators.

\section{Acknowledgments}

The research was carried out with the financial support of the Russian Foundation for Basic Research and administration of Krasnodar Territory within the framework of scientific project nr. 19-44-233004 r_mol_a.

\section{References}

1. WMO-No. 1203. WMO Guidelines on the Calculation of Climate Normals, 29, (WMO: Geneva, Switzerland, 2017)

2. J.M. Caprio, H.A. Quamme, Can. J. Plant Sci., 82(4), 755-763 (2002) https://doi.org/10.4141/P01-160

3. B. Bois, A. Blais, M. Moriomdo, G. Jones, IXe International Terroirs Congress, 17-20 (2012) https://www.researchgate.net/publication/278745872

4. C.G. Ferretti, Ecol. Indic., 108, 105737 (2020) http://doi.org/10.1016/j.ecolin d.2019.105737

5. C. Liles, D.C Verdon-Kidd, Aust. J. Grape Wine Res., 26(4), 343-357 (2020) https://doi.org/10.1111/ajgw.12447

6. J.D. Anderson, G. V. Jones, A. Tait, A. Hall, M.C. Trought, OENO One, 46(3), 149165 (2012) https://doi.org/10.20870/oeno-one.2012.46.3.1515

7. M. Ruml, A. Vuković, M. Vujadinović, V. Djurdjević, Z. Ranković-Vasić, Z. Atanacković, B. Sivčev, N. Marković, S. Matijašević, N. Petrović, Agric. Forest Meteorol., 158-159, 53-62 (2012) https://doi.org/10.1016/j.agrformet.2012.02.004

8. K. Szenteleki, M. Ladányi, M. Gaál, G. Zanathy, Gy. Bisztray, Appl. Ecol. Environ. Res., 10(1), 87-105 (2012) 
9. H. Quénol, M. Grosset, G. Barbeau, C. van Leeuwen, M. Hofmann, C. Foss, L. Irimia, J. Rochard, J.P. Boulanger, C. Tissot, C. Miranda, Bulletin de l'OIV, 87, 395-406 (2014)

10. B. Omazić, M. Prtenjak, I. Prša, A.B. Vozila, V. Vučetić, M. Karoglan, J. Karoglan Kontić, Ž. Prša, M. Anić, S. Šimon, I. Güttler, Int. J. Climatol., 40(2), 5634-5655 (2020) https://doi.org/10.1002/joc.6541

11. G.V. Jones, M.A. White, O.R. Cooper, K. Storchmann, Climatic Change, 73, 319-343 (2005) http://doi.org/10.1007/s10584-005-4704-2

12. D. Tomasi, G.V. Jones, M. Giust, L. Lovat, F. Gaiotti, Am. J. Enol. Vitic., 62, 329-339 (2011) http://doi.org/10.5344/ajev.2011.10108

13. G. Koufos, T. Mavromatis, S. Koundouras, N.M. Fyllas, In: C.G. Helmis, P.T. Nastos (eds) Advances in Meteorology, Climatology and Atmospheric Physics, 555-561 (Springer Atmospheric Sciences, 2012) https://doi.org/10.1007/978-3-642-29172-2_79

14. H. Fraga, A.C. Malheiro, J. Moutinho-Pereira, J.A. Santos, Food Energy Secur., 1, 94110 (2013) https://doi.org/10.1002/fes3.14

15. A. Alikadic, I. Pertot, E. Eccel, C. Dolci, C. Zarbo, A. Caffara, R. De Filippi, C. Furlanello, Agric. Forest Meteorol., 271, 73-82 (2019) https://doi.org/10.1016/j.agrformet.2019.02.030

16. A. Palliotti, S. Tombesi, O. Silvestroni, V. Lanari, M. Gatti, S. Poni, Sci. Hortic., 178, 43-54 (2014) https://doi.org/10.1016/j.scienta.2014.07.039

17. M. de la Fuente, R. Linares, J. R. Lissarrague, Wine Vitic. J., 31(1), $43-46$ (2016)

18. C. van Leeuwen, A. Destrac-Irvine, M. Dubernet, E. Duchêne, M. Gowdy, E. Marguerit, P. Pieri, A. Parker, L. de Rességuier, N. Ollat, Agronomy, 9, 514 (2019) https://doi.org/10.3390/agronomy9090514

19. G. Gutiérrez-Gamboa, W. Zheng, F.M. de Toda, Food Res. Int., 139, 109946 (2021) https://doi.org/10.1016/j.foodres.2020.109946

20. V.S. Petrov, G.Yu. Aleynikova, L.Yu. Novikova, L.G. Naumova, A.A. Lukyanova, Fruit growing and viticulture of South Russia, 57(3), 29-50, https://doi.org/10.30679/2219-5335-2019-3-57-29-50

21. L.Yu. Novikova, L.G. Naumova, Vavilov Journal of Genetics and Breeding, 23(6), 142-149 (2019) https://doi.org/10.18699/VJ19.551

22. S. Korsakova, In: Attri S., Rathore L., Sivakumar M., Dash S. (eds) Challenges and Opportunities in Agrometeorology, 385-296 (Springer, Berlin, Heidelberg, 2011) https://doi.org/10.1007/978-3-642-19360-6_29

23. E.A. Chernikov, V.P. Popova, O.V. Yaroshenko, A.A. Marmorshtein, Russ. Agricult. Sci., 47, 143-147 (2021) https://doi.org/10.3103/S1068367421020051

24. O.D. Sirotenko, V.N. Pavlova, In: S.M. Semenov (ed) Methods for assessing the effects of climate change on physical and biological systems, 165-189 (Moscow, Rosgidromet, 2012) 